\title{
Two new species of Bittacidae (Mecoptera) from the Amazon Basin
}

\author{
Norman D. Penny ( $\left.{ }^{(}\right)$
}

\begin{abstract}
Two new species of Bittacidae (Mecoptera) from Humboldt Biological Reserve, Mato Grosso state, Brazil, are described and ecological notes are given.
\end{abstract}

\section{INTRODUCTION}

Although several species of Mecoptera have been described from southern Brazil (Souza Lopes \& Mangabeira, 1942, and Morgante, 1967), only one species has been recorded from the Amazon Basin. Thus, it was with considerable interest that recent collections of INPA (Instituto Nacional de Pesquisas da Amazônia) turned up nine specimens representing three different species. Two of these species are new, and are herein described.

\section{Neobittacus aripuanaensis n. sp.}

Description based on 1 male, 2 females, pinned.

HEAD: Tan shading to brown on rostrum, covered with sparse whitish pubescence. Compound eyes brown to black, large, widely separated. Ocellar triangle brown, large. Median ocellus amber to brown, located between antennal bases. Maxillary palpi dark brown, five-segmented. Labial palpi brown, twosegmented. Antennal scape and pedicel tan; flagellum tan, consisting of 22 elongate segments with short, brown pubescence. Antennal length about $8 \mathrm{~mm}$.

THORAX: Pro-, meso-, and metanotum tan with short, tawny pubescence. Pronotum with two anterior and four posterior large, black spines. Mesonotal scutum with lateral protuberances each bearing 1 to 3 large, black spines. Scutellum of meso- and metanotum each bearing two large, black spines. Pleural regions dark brown with fine whitish pubescence.

LEGS: Coxae dark brown with many long, yellowish setae. Femora and tibiae tan, becoming dark brown at apex; annular setae dark brown; spines black. Tibial spurs light brown. Tarsi dark brown with numerous darker setae and spines. First tarsal segment as long as next three together.

WINGS: Forewing $25 \mathrm{~mm}$. long, falcate at tip (fig. 1). Base color light amber with dark brown margining most crossveins and vein forks. Alternating pattern of dark and light between $R 1$ and $S 1+2(R 2+3)$. First series of crossveins forming nearly straight, continuous line from $\mathrm{S} 1+2$ to $\mathrm{CuA}$. Large white thyridium at first fork of $\mathrm{M}$. From three to 5 costal crossveins beyond basal crossvein. Subcostal crossvein far distad of radial sector fork and slightly proximal of apex of Sc. Apical crossvein absent. Hindwing similar to forewing.

ABDOMEN OF MALE: Segments 2 to 8 with mottling of tan and dark brown; with fine, whitish pubescence. Dorsal lobes of ninth tergum tan, becoming dark brown apically; much longer than basistyles; covered with whitish pubescence (fig. 2). Inner surface of dorsal lobes with pockets with openings directed anteriad (figs. 3\&4). Margin of pocket openings bearing ventro-mesal lobe and numerous stout spines. Patch of small spines on inner surface of dorsal lobes near bases. Basistyles dark brown with whitish pubescence. Dististyles small, brownish. Cerci dark brown, not reaching to tip of dististyles. Aedeagus amber, simply recurved. Proctiger not visible.

ABDOMEN OF FEMALE Segments 2 to 9 brown with fine, whitish pubescence. Cerci smail, dark brown.

( " ) - Instituto Nacional de Pesquisas da Amazônia, Manaus 
BODY LENGTH: 18 to $23 \mathrm{~mm}$. (holotype, $20 \mathrm{~mm}$.).

Holotype male and paratype female, BRAZIL: Mato Grosso, Humboldt Biological Reserve at Dardanelos Falls on the Aripuaná River $\left(10^{\circ}\right.$ $\left.11^{\prime} \mathrm{S}, 59^{\circ} 48^{\prime} \mathrm{W}\right), 2-X-1975$, Lindalva Paes de Albuquerque and J. B. Moraes. Allotype, same data as holotype, but 27-IX-1975, at light. All types deposited with the Entomology MuseumINPA, Manaus.

VARIATION: Number of costal crossveins varies from 4 in both forewings of the holotype and left forewing of paratype to 6 in both forewings of allotype.

DAMAGE: Holotype has wrinkled wings, as if the specimen had been placed in fluid at one time. In addition, 3 entire legs and tarsal segments of two others are missing. Only the base of one antenna remains. Allotype is missing left hindleg and tarsal segments of three others. Paratype is missing left midleg and tarsal segments from two others.

This species was named after the river valley in which it was collected. It appears to be closely related to Bittacus andinus Londt \& Byers, but the large number of costal crossveins readily places this species in the genus Neobittacus, which heretofore had been known from only one species, Neobittacus blancheti (Pictet). Neobittacus aripuanaensis can be separated from this other species of Neobittacus by its smailer size, reduced pigmentation of the wings, and length and configuration of the dorsal lobes of the male ninth. tergum. The similarities among Bittacus andinus and the two species of Neobittacus point out the close relationship between the two genera.

This species was collected in a moist, upland, primary forest at approximately $300 \mathrm{~m}$. elevation. Dominant trees included Cousapoa $\mathrm{sp}$. (Moraceae), Swietenia macrophylla King (Meliaceae), and Bertholletia excelsa HB. (Lecythidaceae). Understory trees included Socrotea exorrhiza (Mart.) H. Wendl. (Palmae), with a ground cover of Selaginella sp. For a more complete review of the flora of this area, see Lisboa et al., 1976. Three days of intensive collecting in the type locality in mid-March failed to yield additional specimens.

\section{Pazius ornaticandus n. sp.}

Description based on 1 male, 2 females, pinned.

HEAD: Black with fine whitish pubescence. Compound eyes dark plum, large, meeting at mid-line below antennae; occupying most of surface area of head. Ocellar triangle black, raised above vertex. Lateral ocelli caudad of antennae; median ocellus between antennae. Rostrum dark brown with scattered setae and patch of denticles on caudal surface. Scape, pedicel, and 19 flagellar segments dark brown. Antennal length about $3 \mathrm{~mm}$.

THORAX: Pro-, meso-, and metanotum dark brown with short, whitish pubescence; without spines. Pleural regions dark brown with fine whitish pubescence.

Legs: Forefemora tawny basally, dark brown apically. Foretibiae tibial spurs and Ist tarsal segment tawny. Other tarsal segments of forelegs dark brown. Midfemora dark brown, becoming tawny at apex. Midtibiae and tarsi dark brown. Hindfemora and tibiae dark brown basally, becoming tawny at apex. Proximal half of Ist tarsal segment of hind leg tawny. Distal half of Ist tarsal segment and all other tarsal segments dark brown. Spines on all legs dark brown. First tarsal segment of fore- and midlegs about equal in length to distal 4 tarsal segments together. First tarsal segment of hindleg only about half the length of same segment in fore- and midlegs and two-thirds length of distal 4 tarsal segments together.

WINGS: Forewing $16 \mathrm{~mm}$. long, and very narrow. Wings clear, except for darkened stigma (fig. 5). Subcostal crossvein at or very near to radial sector fork. Apical crossvein absent, but crossvein between $\mathrm{CuA}$ and M4 . Two thyridial spots between $S(R)$ and $M$, and between $\mathrm{S} 3+4$ and $\mathrm{M} 1+2$. Hindwing similar to forewing .

ABDOMEN OF MALE: Segments 2 to 5 light brown. Segments 6 to 8 dark brown. Dorsal lobes of ninth tergum tawny, with caudal surface forming dorsal and ventral points, and mesally-directed ridge between points; slightly longer than basistyles (fig. 7). Dorso-caudal 

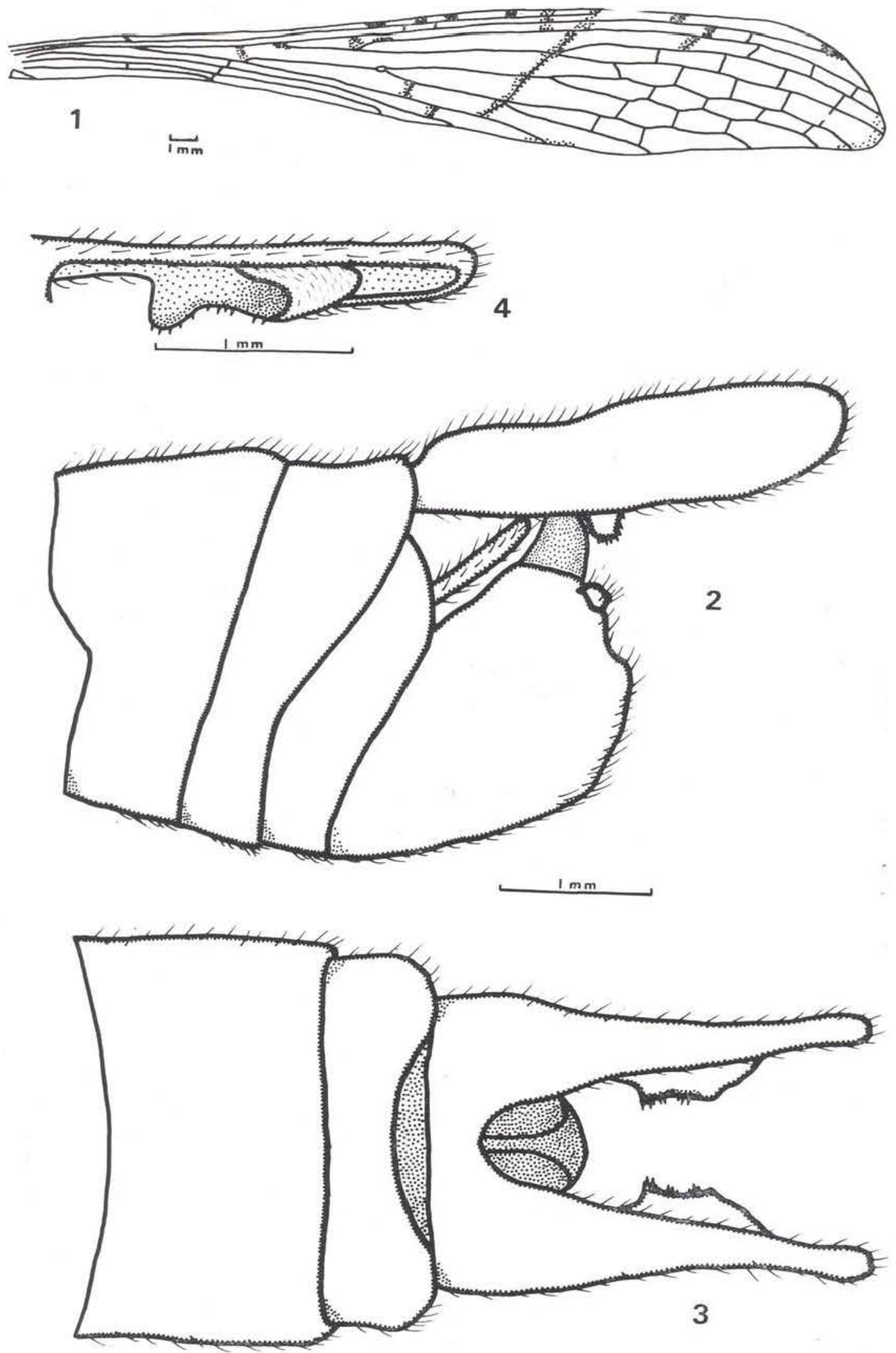

Fig. 1-4 - Neobittacus aripuanaensis. Fig. 1, right forewing of allotype. Fig. 2, lateral view of tip of abdomen, holotype. Fig. 3, same, dorsal view. Fig. 4, dor so-lateral view of mesal surface of dorsal lobes, holotype 


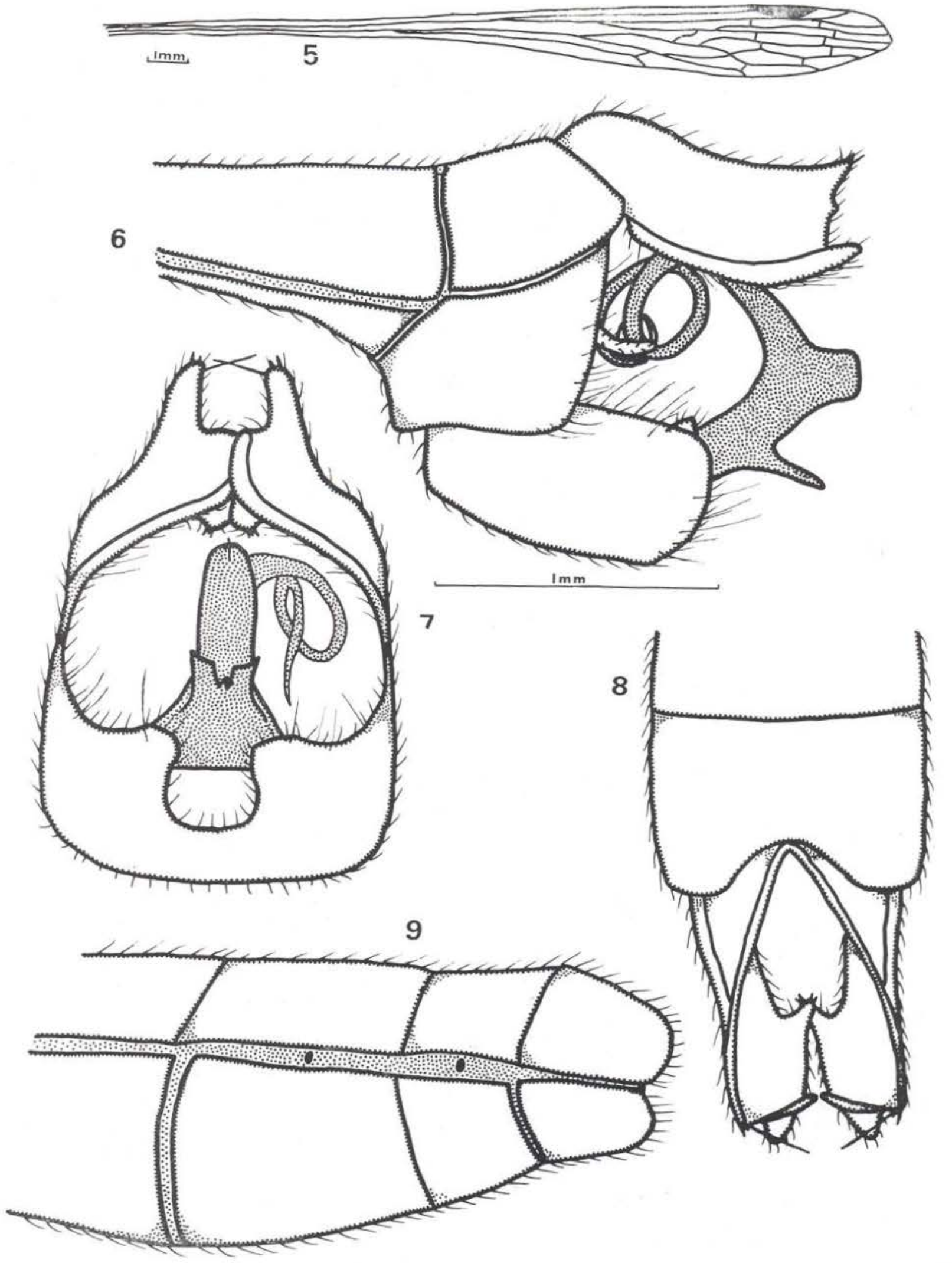

Fig. 5-9 - Pazius ornaticaudus. Fig. 5, right forewing of allotype. Fig. 6, holotype. lateral view of tip of abdomen. Fig. 7, same, ventro-caudal view. Fig. 8, same, dorsal view. Fig. 9, paratype, lateral view of tip of abdomen. 
point bearing two spines and mesally-directed, stout seta. Ventral surface of dorsal lobes with anterio-mesally-directed, spinous projection. Basistyles and dististyles dark brown with long, dark pilosity. Cerci dark brown, not reaching tip of basistyles (fig. 6). Aedeagus amber, with pair of caudal protuberances near base; large, rounded, dorso-caudally-directed projection above protuberances, and twice recurved tip (fig. 8) .

ABDOMEN OF FEMALE: Segments 2 to 9 dark brown with fine, whitish pubescence. Cerci very small, difficult to observe (fig. 9).

BODY LENGTH: Approximately $23 \mathrm{~mm}$.

Holotype male, BRAZIL: Mato Grosso, Humboldt Biological Reserve at Dardanelos Falls $\left(10^{\circ} 116, \mathrm{~S}, 59^{\circ} 48^{\prime} \mathrm{W}\right)$ on the Aripuanã River, 21-III-1977, Norman D. Penny. Allotype and paratype females, same data as holotype, but collected 18-III-1977 and 20-III-1977, respectively. All types deposited with the Entomology Museum-INPA, Manatis.

VARIATION: The color pattern of the two females is somewhat darker than that of the male, forming a striking pattern of dark legs with light bands at the apex of femur and tibia and base of first tarsal segment.

DAMAGE: All three specimens appear to be in perfect condition.

This species was named for the ornate aedeagus of the male. It is most closely related to $P$. furcatus Byers, but differs in the more elaborate aedeagus and configuration of the dorsai lobes. The reduced size of the female cerci may also be characteristic.

This species was collected in moist, upland, primary forest at approximately $300 \mathrm{~m}$. elevation. Dominant trees included Bertholletia excelsa HB. (Lecythidaceae). Understory trees included Socrotea exorrhiza (Mart.) H. Wendl (Palmae), with a thick ground cover of
Selaginella sp. insect associates included Tipulidae, Micropezidae, Dolichopodidae, Ichneumonidae, and Cercopidae. Mecopterans were quite scarce, as 4 days of intensive search yielded only 3 insects.

\section{ACKNOWLEDGMENTS}

I wish to thank Anthony B. Anderson for plant identifications, and George W. Byers for a drawing of the holotype of Neobittacus blan. cheti (Pictet).

\section{Resumo}

Duas novas espécies de Bittacidae (Mecoptera) da Reserva Biológica Humboldt, Estado de Mato Grosso, Brasil, são descritas com todos os dados ecológicos observados.

\section{LITERATURE CITED}

BYERS, G.W

1957 - The neotropical genus Pazius (Mecoptera: Bittacidae), Occ. Pap. Mus. Zool. Univ. Mich. 582, 1-7; Ann Arbor.

Lisboa, P.L.; Prance, G.T. \& Lisboa, R.L.

1976 - Contribuição ao conhecimento da Flora do Aripuanã (Mato Grosso). I. Fanerógamas. Acta Amazonica. Suplemento, 6(4):33-41.

LONDT, J.G.H. \& BYERS, G.W.

1974 - A new neotropical Bittacus with maculate wings (Mecoptera: Bittacidae). J. Kansas ent. Soc., 47:344-348.

MORGANTE, J.S.

1967 - Duas novas espécies de Bittacus Latreille 1807 (Mecoptera, Bittacidae). Papéis avulsos Depart. Zool., 20:55-58.

Souza Lopes, H. de \& Mangabeira, O.

1942 - Sobre algumas espécies brasileiras do gênero "Bittacus" Latr., 1207, com a descrição de três espécies novas (Panorpatae, Bittacidae). Revista Brasil. Biol., 2:331-341. 